\section{Ensidig fordømmelse av Israel}

Mads Gilbert og Erik Fosse hevder i Tidsskriftet nr. 24/2009 at øyenvitnenes politiske farge var uvesentlig under krigen i Gaza (1). De tar Tidsskriftets redaksjon og Trond Markestad i forsvar og fremfører beskrivelser av den humanitære situasjonen sammen med nok et partsinnlegg om konflikten.

Objektivt? Hamas har styrt Gaza siden 2007. De støttes militært av Iran, som ønsker å tilintetgjøre Israel. Det er ikke bare Israel som truer pressefriheten i Gaza (2). Palestinske journalister har søkt asyl i Norge etter forfølgelser og trusler fra Hamas (3). Amnesty International rapporterer at Hamas torturerer og dreper sine palestinske motstandere i Gaza, og omfanget økte i forbindelse med Gaza-krigen. Pasienter ble likvidert av Hamas. Også ved Shifasykehuset der Gilbert og Fosse arbeidet, ble pasienter skutt i sengene (4).

500 mennesker ble drept og ca. 8000 skadet i selvmordsaksjoner inne i Israel i årene 2000-07, mange utført av Hamas (5). Antallet selvmordsaksjoner er redusert betydelig de siste årene gjennom sikringstiltak fra israelsk side, blant annet streng grensekontroll. Gaza har også grense mot Egypt, som deltar aktivt i blokaden, selv om mediene har fokusert lite på dette. Egypterne ønsker minst mulig befatning med Iran-støttet islamisme i området.

I 2008 ble 1750 Hamas-raketter sendt innover israelsk område, og siden 2001 er 15 israelere drept i disse angrepene. Palestinere brukes som levende skjold, mens israelske menn, kvinner og barn løper i tilfluktsrommene flere ganger daglig. Gilbert sammenlikner disse angrepene med norsk motstandskamp under den annen verdenskrig (6). Amnesty International har definert selvmords- og rakettangrepene som overgrep mot både palestinsk og israelsk sivilbefolkning og fordømmer angrepene som kriminalitet mot menneskeheten og mot internasjonal lov (7). Israel frykter at Iran skal forsyne Hamas med langtrekkende og mer ødeleggende raketter, og tar på alvor at Hamas går inn for destruksjon av Israel gjennom hellig krig.

Genève-konvensjonen, Folkeretten og menneskerettighetene brytes systematisk og med overlegg i kampen mot staten Israel. Den ensidige fordømmelsen av Israel er ikke bare ulogisk, men også lite tjenlig for å få til en varig fredsløsning i området. Også redaksjonen av fagtidsskriftet og lederen for etikkrådet har et ansvar i denne sammenheng.

\section{Ragnvald B. Petersen \\ Sandnes \\ Litteratur \\ 1. Fosse J, Gilbert M. Objektivt i Gaza. Tidsskr Nor Legeforen 2009; 129: 2629-30.}

2. The UN Refugee Agency. Freedom of the Press 2008 - Israeli-occupied territories/Palestinian authority. www.unhcr.org/refworld/country., FREEHOU, .PSE, 4871 f60ec, 0 .html (6.4.2010).

3. Journalisten. Tre palestinske journalister i asylmottak. www.journalisten.no/story/48011 (6.4.2010).

4. Amnesty International. Palestinian Authority: Hamas' deadly campaign in the shadow of the war in Gaza. www.amnesty.org/en/library/asset/ MDE21/001/2009/en/9f210586-f762-11dd-8fd7f57af21896e1/mde210012009en.html (6.4.2010).

5. Israel Ministry of Foreign Affairs. Victims of Palestinian Violence and Terrorism since September 2000. www.mfa.gov.il/MFA/Terrorism-+Obstacle +to+Peace/Palestinian+terror+since+2000/ Victims+of+Palestinian+Violence+and+Terrorism +sinc.htm (6.4.2010)

6. NRK Nett-TV. Dagsrevyen 31.12.2008. www.nrk.no/nett-tv/indeks/154876/ (6.4.2010)

7. Amnesty International. Palestinian Authority: Hamas must stop targeting of civilians. www.amnesty.org/en/library/asset/MDE21/006/ 2006/en/980dd689-d462-11dd-8743-

d305bea2b2c7/mde210062006en.html (6.4.2010).

\section{En misinformerende anmeldelse}

I en anmeldelse af Walter Kraus' bog Mobilstråling i Tidsskriftet nr. 23/2009 misinformerede Arnt Inge Vistnes om indholdet, fordi han kun forholdt sig til elektromagnetiske felter og ikke til tidens stigende mikrobølgebestråling (1).

Modulerede og pulserende elektromagnetiske bølger eller stråler, der bruges ved UMTS (Universal Mobile Telecommunications System) og trådløse mobile bredbånd som WiFi (Wireless Fidelity) og Wlan (Wireless Local Area Network) blev forbigået i tavshed. Anmeldelsen blev desværre kun fulgt op af henvisninger til litteratur, der omtaler forskning med elektromagnetiske felter.

Der er så megen forskning, som frasorteres i disse år, og som det er vigtigt at nævne, fordi børn er en sårbar gruppe. I over 60 år har russerne foretaget dyre- og vævsforskning med elektromagnetiske felter og stråler, og allerede i 1965 meldte de ud om negative biologiske følgevirkninger af mikrobølger (2). Den nu 84-årige professor Yuri Grigoriev er stadig forskningsaktiv, og han har blandt andet ud fra forsøg med eksponerede dyreæg (3), advaret imod mobilbrug hos børn, for jo yngre væv der eksponeres, jo større er risikoen for vævsskader $(4,5)$.

Rusland, Kina og Italien har lavere grænseværdier end de grænseværdier, som den selvsupplerende kommission ICNIRP (International Commission on Non-Ionizing Radiation Protection) har fastsat, fordi kommissionens grænseværdier kun tager højde for en akut termal skadevirkning. Vistnes vurderer imidlertid gældende standarder som tilstrækkelige. Han omtaler slet ikke mulige non-termale biologiske skadevirkninger, selv om de er veldokumenteret (6).

I Ægypten er der blevet foretaget ekspo- neringsforsøg med mikrobølger på fostre og nyfødte børn, som fik hjerteforstyrrelser (7), og i Grækenland er mus blevet eksponeret i flere generationer, indtil de blev sterile (8). Disse resultater er meget vigtige, fordi børn er en udsat gruppe, og fordi vi mennesker får sværere og sværere ved at reproducere os selv. Børn kan ikke beskytte sig selv imod en ukendt og usynlig mobilstrålingsfare, og selvfølgelig skal vi alle informeres om denne stigende trådløse forureningstrussel, som Vistnes fejede væk med et pennestrøg.

\section{Bente-Ingrid Bruun}

Danmark

\section{Litteratur}

1. Vistnes Al. Tendensiøst om stråling. Tidsskr Nor Legeforen 2009; 130: 2510-11.

2. Presman AS. The action of microwaves on living organismes biological structures. Soviet Physics Uspekhi 1965; 8: 463-88.

3. Grigoriev J. Biological effects of mobile phone electromagnetic field on chick embryo lrisk assessment using the mortality rate). Radiats Biol Radioecol 2003; 43: 541-3.

4. Bruun BI. De trådløse samfund - myter \& fakta. Bilag C. København: Books on Demand, 2009.

Center for Electromagnetic Safety. www.tesla.ru/ english/protection/expert.html (26.3.2010).

6. Belyaev I. Non-thermal biological effects of microwaves: current knowledge, further perspective and urgent needs. www.cost281.org/download.php?fid $=714(26.3 .2010)$.

7. Rezk A, Abdulquawi K, Mustafa RM et al. Fetal and neonatal responses following maternal exposure to mobile phones. Saudi Med J 2008; 29: 218-23.

8. Magras IN, Xenos TD. RF radiation-induced changes in the prenatal development of mice. Bioelectromagnetics 1997; 18: 455-61.

\section{Dr. Hyde?}

I Tidsskriftet nr. 6/2010 undrer Robin Holtedahl seg over at jeg har valgt å bruke navneparet dr. Jekyll og dr. Hyde om to legeskikkelser (1). Han henviser til et intervju i Tidsskriftet nr. 24/2009 (2) og boken Penger og verdier $i$ helsetjenesten (3). Holtedahl skriver: «Om det skyldes uvitenhet fra forfatterens side er uklart, men uansett vil lesere av Robert Louis Stevenson vite at dr. Jekylls onde alter ego het mr. Hyde, og slett ikke var lege» (1). Kapitlet det er snakk om, Penger i sykehus - dr. Jekylls lidelse (4), åpner med følgende sitat: «Det var i moralen, i min egen personlighet, jeg lærte at mennesket er gjennomgående og opprinnelig dobbelt. Av de to naturene som sloss om herredømmet i min egen bevissthet, forsto jeg, selv om jeg med rette kunne hevde at jeg var enten det ene eller andre, at jeg faktisk dypest sett var begge.» Sitatet er fra Stevensons verk Doktor Jekyll og herr Hyde (5) som er referert i kapitlet. Min tekst er bygd opp omkring en dialog mellom to fiktive klinikere som jeg har kalt dr. Jekyll og dr. Hyde. Navnevalget bunner ikke i uvitenhet. Jeg valgte dr. Hyde og ikke herr Hyde, eller det engelske mr. Hyde, fordi teksten dreier seg om to leger. De to 
legene representerer to ulike strategier i møte med innsatsstyrt finansiering. Holtedahl mener det er å gå for langt å gi leger status som «monstre» om de tar mer hensyn til sykehusets budsjetter enn pasientenes behov og interesser. Jeg er enig, og vil understreke at jeg ikke har ytret meg i slike vendinger. Hensikten med mine uttalelser i Tidsskriftet (3) og bidraget i boken Penger og verdier $i$ helsetjenesten har vært å belyse det krysspresset som klinikeren kan møte mellom faglige og økonomiske hensyn, og å rette søkelyset mot svakheter knyttet til finansieringsordningen for spesialisthelsetjenesten.

\section{Jan C. Frich}

Institutt for helse og samfunn

Universitetet i Oslo

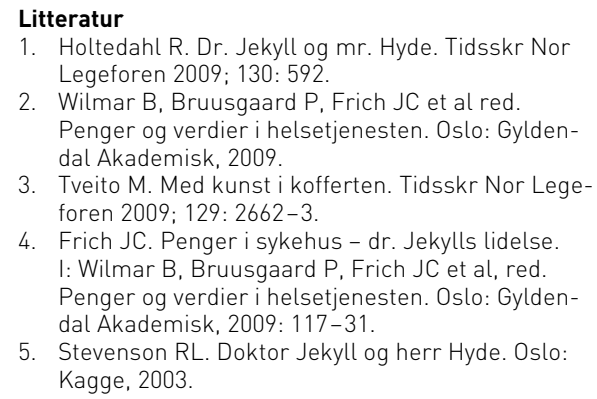

\section{Behandling av multippel sklerose}

I en for øvrig utmerket artikkel om behandlingen av multippel sklerose (MS) skriver Kjell-Morten Myhr ved Nasjonalt kompetansesenter for MS at natalizumab er annenlinjebehandling som kun er indisert ved gjentatte attakker på tross av førstelinjebehandling (betainterferon og glatirameracetat) (1). Dette er imidlertid bare halve sannheten. I Norge er natalizumab godkjent også som førstelinjebehandling ved raskt utviklende alvorlig relapserende, remitterende mutippel sklerose. Dette er i tråd med European Medicines Agency og Food and Drug Administration, og er et viktig poeng som ikke bør underkommuniseres.

Bruken av natalizumab er begrenset av risikoen for utvikling av progressiv multifokal leukoencefalopati (PML), en alvorlig og ofte dødelig hjerneinfeksjon forårsaket av JC-virus. Hvorfor kan det likevel være riktig å bruke natalizumab som førstelinjebehandling ved alvorlig multippel sklerose? Multifokal leukoencefalopati ser ut til å ramme om lag $0,1 \%$ og risikoen synes å øke med behandlingstiden. Denne risikoen må veies mot behandlingsgevinsten. Sammenliknende studier med betainterferon og glatirameracetat har ikke vært utført, men ut fra placebokontrollerte studier har natalizumab betydelig bedre effekt både på reduksjon av attakker og utvikling av inva- liditet. Pasienter med multippel sklerose som har hatt to eller flere alvorlige anfall i løpet av et år og som har uttalte radiologiske tegn på sykdomsaktivitet, vil med stor grad av sannsynlighet utvikle betydelig invaliditet relativt raskt. Deres leveutsikter er også redusert. Effekten av behandling er størst tidlig i sykdomsforløpet. I en slik situasjon er det derfor etter vårt skjønn rimelig at pasienten får mulighet til å velge den mest effektive behandlingen, uten å måtte gå veien om betainterferon eller glatirameracetat som har mer begrenset effekt.

Det er et tankekors at en behandlingsstrategi som begrenser natalizumab til annenlinjebehandling gjør at pasientene får denne behandlingen på et tidspunkt der effekten ikke lenger er maksimal, mens risikoen for progressiv multifokal leukoencefalopati vil være den samme. Et annet tankekors er at førstelinjebehandling med natalizumab er godt dokumentert (2), mens effekten av natalizumab som monoterapi ved annenlinjebehandling ikke er dokumentert.

\section{Trygve Holmøy \\ Hanne F. Harbo \\ Elisabeth Gulowsen Celius}

Oslo universitetssykehus, Ullevål

\section{Litteratur}

1. Myhr KM. Medikamentell behandling av multippel sklerose. Tidsskr Nor Legeforen 2010: 130: 490-2.

Polman CH, O'Connor PW. Havrdova E et al. A randomized, placebocontrolled clinical trial of natalizumab for relapsing multiple sclerosis. $\mathrm{N}$ Engl J Med 2006; 354: 899-910.

\section{K.-M. Myhr svarer:}

Takk til Holmøy og medarbeidere for viktige kommentarer og refleksjoner til artikkelen om medikamentell behandling av multippel sklerose (1).

Indikasjon for natalizumabbehandling ved multippel sklerose i Norge er en av følgende (2):

- Attakkvis multippel sklerose som til tross for førstelinjebehandling gir minst to moderate til alvorlige attakker siste år, eller tre attakker siste to år, eller ett attakk siste år med vedvarende betydelig funksjonssvikt.

- Raskt utviklende attakkvis multippel sklerose med minst to moderate til alvorlige attakker med betydelig funksjonssvikt i løpet av ett år, med samtidig krav til sykdomsaktivitet målt ved magnetisk resonanstomografi.

- Attakkvis multippel sklerose der det er uttalte bivirkninger/overfølsomhet for førstelinjebehandling.

Omtalte artikkel hadde bredt fokus mot både førstelinje- og annenlinjetjenesten, og alle detaljer om indikasjoner var ikke inkludert, men i stedet henvist til i retningslinjer (2). Første punkt var omtalt i artikkelen og utgjør klart flertallet av pasienter som er aktuelle for natalizumabbehandling. Pasienter med gjentatte alvorlige attakker ved førstegangsvurdering med indikasjon for natalizumab som førstelinjebehandling utgjorde kun $6 \%$ av natalizumabbehandlede pasienter i en dansk studie. Der er indikasjonsstillingen tilsvarende den vi har i Norge (3). Dersom anslagsvis $20 \%$ av totalt antall behandlede pasienter i førsteog annenlinjetjenesten mottar natalizumab, utgjør dette kun et fåtall av behandlede pasienter. Ved en aktiv strategi for tidlig behandling vil man vanligvis allerede ha startet førstelinjebehandling, og et eventuelt skifte til natalizumab skjer først dersom det raskt skulle tilkomme nye attakker. Men i noen sjeldne tilfeller kommer attakkene såpass tett at førstelinjebehandling ikke er startet, og nevnte indikasjon for natalizumab er da aktuell.

Årsaken til at natalizumab ikke er førstelinjebehandling er risiko for utvikling av potensielt dødelig progressiv multifokal leukoencefalopati (PML). Siste oppdatering viser nå over 45 tilfeller av multifokal leukoencefalopati, med økende risiko avhengig av behandlingslengde, estimert til $0,14 \%$ ved behandling i 24-36 måneder. Men ved svært aktiv multippel sklerose anser man likevel at den potensielle gevinsten av behandlingen overstiger risikoen for utvikling av multifokal leukoencefalopati.

Vi står overfor det paradoks at behandlingen med best effekt som hovedregel ikke kan nyttes som førstelinjebehandling, til tross for at tidlig behandling gir størst potensial for stabilisering av sykdommen. Manglende dokumentasjon for natalizumab som annenlinjebehandling er dog ikke riktig. I den omtalte danske studien rapporterte man effekt på attakkraten i klinisk praksis, på lik linje som ved førstelinjebehandling for svært aktiv multippel sklerose (3). Forhåpentligvis vil vi også i løpet av nær fremtid ha tilgjengelig annen behandling med effekt oppimot det vi ser ved natalizumab, uten risiko for multifokal leukoencefalopati (4).

\section{Kjell-Morten Myhr}

Haukeland universitetssykehus

Litteratur

1. Myhr KM. Farmakologisk behandling av multippel sklerose. Tidsskr Nor Legeforen 2010; 130: 490-2.

2. Bekkelund SI, Dietrichs E, Celius EG et al. Behandling av multippel sklerose (MS) med natalizumab. Oppstart, gjennomføring og avslutning av behandling. Oslo: Helsedirektoratet, 2007.

3. Oturai AB, Koch-Henriksen N, Petersen T et al. Efficacy of natalizumab in multiple sclerosis patients with high disease activity: a Danish nationwide study. Eur J Neurol 2009: 16: 420-3.

4. Carroll WM. Oral therapy for multiple sclerosis sea change or incremental step? N Engl J Med 2010; 362: 456-8. 